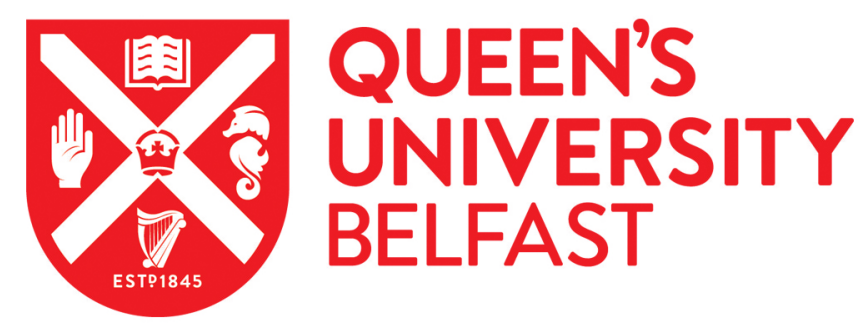

\title{
Crystallisation kinetics and phase transformation behaviour of electroless nickel-phosphorus deposits with high phosphorus content
}

Keong, K. G., Sha, W., \& Malinov, S. (2002). Crystallisation kinetics and phase transformation behaviour of electroless nickel-phosphorus deposits with high phosphorus content. Journal of Alloys and Compounds, 334(12)(1-2), 192-199. https://doi.org/10.1016/S0925-8388(01)01798-4

Published in:

Journal of Alloys and Compounds

Queen's University Belfast - Research Portal:

Link to publication record in Queen's University Belfast Research Portal

\section{General rights}

Copyright for the publications made accessible via the Queen's University Belfast Research Portal is retained by the author(s) and / or other copyright owners and it is a condition of accessing these publications that users recognise and abide by the legal requirements associated with these rights.

Take down policy

The Research Portal is Queen's institutional repository that provides access to Queen's research output. Every effort has been made to ensure that content in the Research Portal does not infringe any person's rights, or applicable UK laws. If you discover content in the Research Portal that you believe breaches copyright or violates any law, please contact openaccess@qub.ac.uk. 


\title{
Crystallisation kinetics and phase transformation behaviour of electroless nickel-phosphorus deposits with high phosphorus content
}

\author{
K.G. Keong*, W. Sha, S. Malinov \\ School of Civil Engineering, Stranmillis Road, The Queen's University of Belfast, Belfast BT7 1NN, UK
}

Received 13 June 2001; accepted 6 August 2001

\begin{abstract}
The effects of continuous heating on the crystallisation kinetics and the phase transformation behaviour of electroless nickelphosphorus deposits plated on mild steel substrates, with high phosphorus contents of 12 and 16 wt.\%, were studied. Both the deposits exhibited an amorphous X-ray profile in the as-deposited condition. The crystallisation temperatures of the deposits increased with decreasing phosphorus content, and increasing heating rate. The activation energies during the crystallisation processes were calculated from the differential scanning calorimetry (DSC) curves of the deposits at heating rates ranging from 5 to $50^{\circ} \mathrm{C} / \mathrm{min}$. It was found that the activation energy is slightly higher in the deposit with lower phosphorus content. X-ray diffraction (XRD) analyses were also conducted on the deposits after heating processes in the DSC apparatus to $300-800^{\circ} \mathrm{C}$ at $20^{\circ} \mathrm{C} / \mathrm{min}$. The sequence of phase transformations was found to be: amorphous phase $\rightarrow$ intermediate metastable phases + stable $\mathrm{Ni}_{3} \mathrm{P}$ phase $(+$ f.c.c. nickel $) \rightarrow$ stable $\mathrm{Ni}_{3} \mathrm{P}$ phase $(+$ f.c.c. nickel). Electron microprobe analysis was carried out on the $16 \mathrm{wt} . \% \mathrm{P}$ deposit and showed that the iron content in the deposit was affected by heating processes. Film growth in the $16 \mathrm{wt} \% \mathrm{P}$ deposit has been shown by scanning electron microscopy (SEM) and electron microprobe analysis on the cross-sections of the deposit after heating to 400 and $800^{\circ} \mathrm{C}$ (at $\left.20^{\circ} \mathrm{C} / \mathrm{min}\right)$. (C) 2002 Elsevier Science B.V. All rights reserved.
\end{abstract}

Keywords: Alloys; Amorphous materials; X-ray diffraction; Phase transitions; Calorimetry

\section{Introduction}

Electroless nickel-phosphorus (EN) deposits can be prepared by the autocatalytic electrochemical reduction of nickel ion in the plating baths. Since the first discovery in 1944 by Brenner and Riddell, various studies have been carried out on these deposits to investigate their microstructural properties and crystallisation behaviour under the influence of deposit compositions and heat treatments. However, many investigators have reported different results as regards both these aspects [1-14]. These differences are believed to be caused by many other related factors such as plating, instrument, measurement, and material factors.

In general, EN deposits are classified into three categories: low (1-5 wt.\%), medium (5-8 wt.\%) and high (9 wt.\% and above) phosphorus deposits [15]. Studies have shown that as-coated low-phosphorus deposits are either crystalline [1,2] or consist of microcrystalline nickel [3].

*Corresponding author.

E-mail address: k.keong@qub.ac.uk (K.G. Keong).
As-coated medium-phosphorus deposits are reported to be either fully amorphous [2] or mixtures of microcrystalline nickel and amorphous phases $[1,4]$. Studies on high-phosphorus as-coated deposits have demonstrated that the deposits could be fully amorphous [1,5,6], mixtures of microcrystalline nickel and amorphous, or consist of these mixtures plus various other phases such as $\mathrm{Ni}_{5} \mathrm{P}_{4}, \mathrm{Ni}_{12} \mathrm{P}_{5}$ and $\mathrm{Ni}_{5} \mathrm{P}_{2}$ [7]. Studies have also indicated that the crystallisation behaviour of EN deposits depends on the level of phosphorus content in the deposits. Study using differential scanning calorimetry (DSC) and transmission electron microscopy (TEM) has revealed that the deposits with less than $7 \mathrm{wt} . \% \mathrm{P}$ transform directly into final stable $\mathrm{Ni}_{3} \mathrm{P}$ phase in a matrix of crystalline nickel [8]. Deposits with higher phosphorus content, however, transform from amorphous to some metastable phases such as $\mathrm{Ni}_{5}(\mathrm{P}, \mathrm{Ni})_{2}$ and $\mathrm{Ni}_{3}(\mathrm{P}, \mathrm{Ni})$ before stable $\mathrm{Ni}_{3} \mathrm{P}$ formation at the end [8]. $\mathrm{X}$-ray diffraction (XRD) analysis has shown that a highphosphorus deposit (12.1 wt.\% P) crystallised to metastable $\mathrm{Ni}_{12} \mathrm{P}_{5}$ phase before transforming to nickel and stable $\mathrm{Ni}_{3} \mathrm{P}$ phase [5]. Different heating conditions also have shown significant influences on both the micro- 
structural properties and crystallisation behaviours of the EN deposits. Study by Randin et al. has indicated that the heated EN deposits consisted of nickel and $\mathrm{Ni}_{3} \mathrm{P}$ phases only [9]. However, other investigators have suggested that some intermediate phases, like $\mathrm{Ni}_{7} \mathrm{P}_{3}$ and $\mathrm{Ni}_{5} \mathrm{P}_{2}$, formed before the transformation to the final stable $\mathrm{Ni}_{3} \mathrm{P}$ phase [10]. Results from DSC and differential thermal analysis (DTA) work on deposits containing 7.4-10 wt.\% $\mathrm{P}$ have shown that the increase in heating rate would delay the crystallisation onset temperature regardless of the phosphorus content [11].

The present study was undertaken to determine the effect of continuous heating process and phosphorus content on the crystallisation kinetics and phase transformation behaviour of EN deposits with high phosphorus content. Samples were heated in the differential scanning calorimeter under different heating rates up to different temperatures, and were further analysed using X-ray diffractometer and scanning electron microscope in order to identify the phases formed.

\section{Experimental procedures}

\subsection{Electroless nickel-phosphorus plating}

The 2.9- $\mu \mathrm{m}$ thick EN deposit with 16 wt.\% P (sample A) used in this work was prepared by the authors. The other deposit (sample B), which was $75 \mu \mathrm{m}$ thick and had a compositional range of 10-14 wt.\% $\mathrm{P}$, was provided by Lea Manufacturing in the UK. The sample with 16 wt.\% P was plated on a nominal $20-\mu \mathrm{m}$ thick mild steel sheet substrate $(30 \times 30 \mathrm{~mm}$ size $)$ using the formulation of plating solution as listed in Table 1 [16].

Surface preparation of the substrate was not carried out, as the mild steel sheet was smooth and clean. During the plating process the mild steel substrate was totally immersed in the plating solution, which was continuously stirred for better agitation. Evaporation from the plating solution was condensed and directed back to the solution. After $1 \mathrm{~h}$, the sample was lifted out from the plating solution and rinsed using clean water before it was weighed. The plating process was repeated up to six times until no significant change in the weight of the sample was observed. The thickness and phosphorus content of the deposit were estimated using SEM and electron micro-

Table 1

Solution composition and plating temperature for the plating of $16 \mathrm{wt} . \% \mathrm{P}$ deposit

\begin{tabular}{ll}
\hline Constituents of solution & Quantity $(\mathrm{g} / \mathrm{l})$ \\
\hline $\mathrm{NiSO}_{4} \cdot 6 \mathrm{H}_{2} \mathrm{O}$ & 40 \\
$\mathrm{NaH}_{2} \mathrm{PO}_{2} \cdot \mathrm{H}_{2} \mathrm{O}$ & 25 \\
$\mathrm{C}_{4} \mathrm{H}_{6} \mathrm{O}_{4}$ & 50 \\
Temperature & $85-95^{\circ} \mathrm{C}$ \\
\hline
\end{tabular}

probe analysis. The EN sample obtained from Lea Manufacturing was prepared by the company using a different plating solution formulation and deposition parameters [17]. However, no repetition was carried out in the plating process. The same kind of substrate but of different thickness was used.

\subsection{Analysis of electroless nickel-phosphorus deposits}

The EN deposits together with their substrates were cut into small square pieces $(3.5 \times 3.5 \mathrm{~mm})$. Continuous heating processes under different constant heating rates of 5 , $10,15,20,30,40$ and $50^{\circ} \mathrm{C} / \mathrm{min}$ were performed in a Netzsch series DSC-404 differential scanning calorimeter in a He flow $(30 \mathrm{ml} / \mathrm{min})$ after evacuating the working chamber. The samples were placed in a ceramic crucible and an empty crucible of the same type was used as a reference. For further analysis of the phase transformation behaviour of the deposits, samples were heated in the DSC apparatus up to temperatures ranging from 300 to $800^{\circ} \mathrm{C}$ $\left(300,350,400,500\right.$ and $\left.800^{\circ} \mathrm{C}\right)$ under a constant heating rate of $20^{\circ} \mathrm{C} / \mathrm{min}$. X-ray diffraction patterns of the samples after heating processes were then recorded at room temperature, using a Siemens diffractometer applying $\mathrm{Cu}$ $\mathrm{K}_{\alpha 1+\alpha 2}$ radiation. Scanning was performed through $3-110^{\circ}$ $(2 \theta)$, with a step size of $0.04^{\circ}$ and counting time of 1 $\mathrm{s} / \mathrm{step}$. To determine the integrated intensities of the X-ray reflections in the XRD profiles, a computer program (ProFit) developed by Hideyo Toraya based on the least squares profile separation technique was used [18]. No reflections were found in the $2 \theta$ angles of $3-20^{\circ}$. The microstructural details and chemical compositions of sample A (16 wt.\% P) in as-deposited condition, and after heating process to temperatures of 400 and $800^{\circ} \mathrm{C}$ at $20^{\circ} \mathrm{C} / \mathrm{min}$, were analysed using scanning electron microscope and electron microprobe at room temperature.

\section{Results and discussion}

\subsection{Effects of phosphorus content}

In the present study, the deposits of both samples A and B (16 and 10-14 wt.\% P) were amorphous in the asdeposited condition (Figs. 1 and 2, bottom), which agreed with the studies on high phosphorus deposits from other investigators $[1,5,6]$. The amorphous profiles with the wide angular range of $35-55^{\circ}(2 \theta)$ were around a $2 \theta$ position corresponding to the nickel $\{111\}$ plane. The iron $\{111\}$, $\{200\}$ and $\{211\}$ diffraction peaks in the XRD profiles of sample A were from the mild steel substrate underneath. They were observed because the coated-deposit was too thin $(2.9 \mu \mathrm{m})$ to totally absorb the penetration of the X-ray beam. The two samples however showed different microstructural characteristics after being heated to different temperatures of $300-800^{\circ} \mathrm{C}$, at a constant heating rate of 


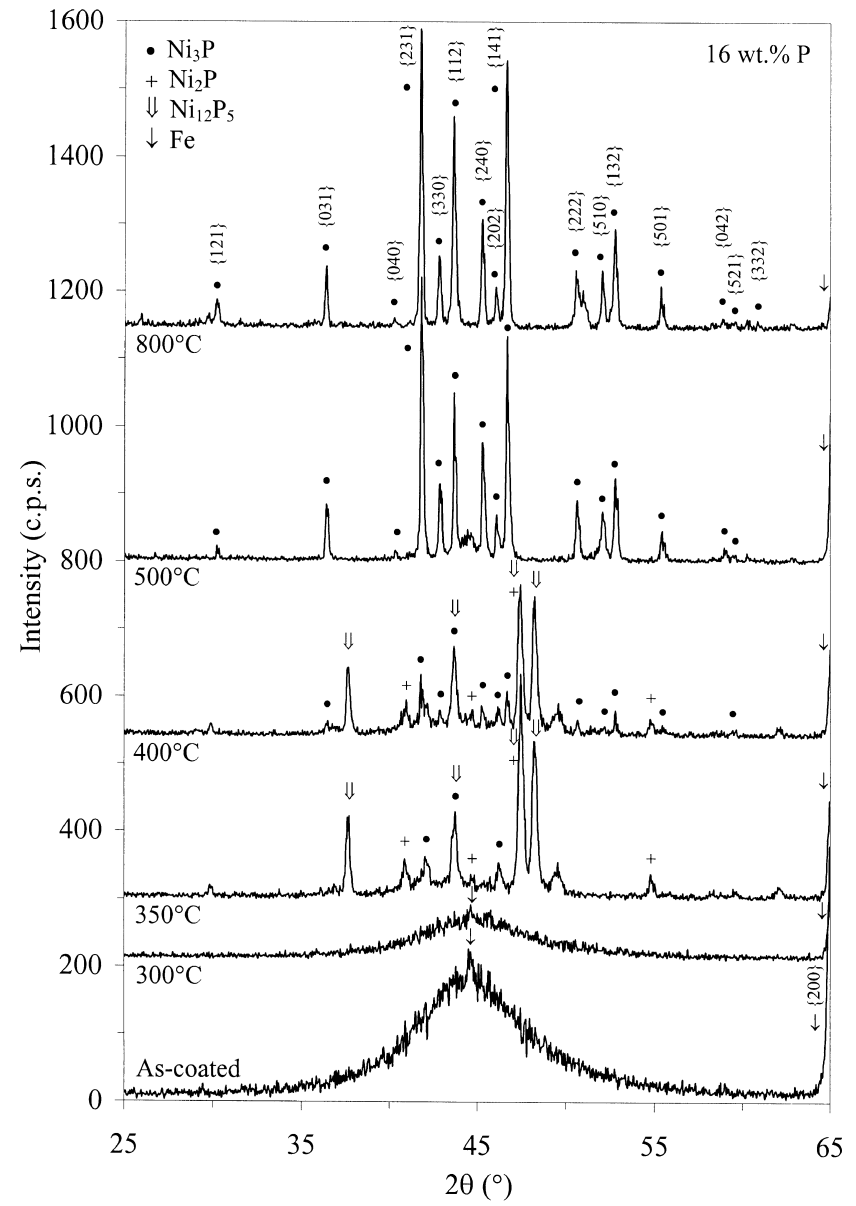

Fig. 1. XRD profiles of the EN deposit with 16 wt.\% $\mathrm{P}$ (sample A) in as-deposited condition and after heating to the end temperatures of $300-800^{\circ} \mathrm{C}$ at $20^{\circ} \mathrm{C} / \mathrm{min}$. For the sake of clarity the XRD profiles were shifted arbitrarily on the vertical scale.

$20^{\circ} \mathrm{C} / \mathrm{min}$ (Table 2). In sample $\mathrm{A}, \mathrm{Ni}_{2} \mathrm{P}$ and $\mathrm{Ni}_{12} \mathrm{P}_{5}$ metastable phases were formed in the deposit after the heating processes to 350 and $400^{\circ} \mathrm{C}$ (Fig. 1). The $\mathrm{Ni}_{3} \mathrm{P}$ stable phase was found after the heating processes to between 350 and $800^{\circ} \mathrm{C}$. In sample $\mathrm{B}, \mathrm{Ni}_{2} \mathrm{P}$ and $\mathrm{Ni}_{12} \mathrm{P}_{5}$ metastable phases were also formed in the deposit after the heating processes to 350 and $400^{\circ} \mathrm{C}$ (Fig. 2). In addition to the $\mathrm{Ni}_{3} \mathrm{P}$ phase, nickel phase was also found in the deposit after the heating processes to between 350 and $800^{\circ} \mathrm{C}$. Hence, the effect of phosphorus content on the microstructural characteristics of the EN deposits was significant.

The phosphorus content of the EN deposits could also affect the phase transformation temperature of the deposits during heating process. The DSC curves in Fig. 3 show that the exothermic temperatures of sample B were higher than those of sample A. In addition, a shoulder was found right before the major exothermic peak of the DSC curves in sample B (Fig. 3b). This shoulder was however not contributed to by the thermally activated reactions from the substrates underneath the coatings, indicated by the flat

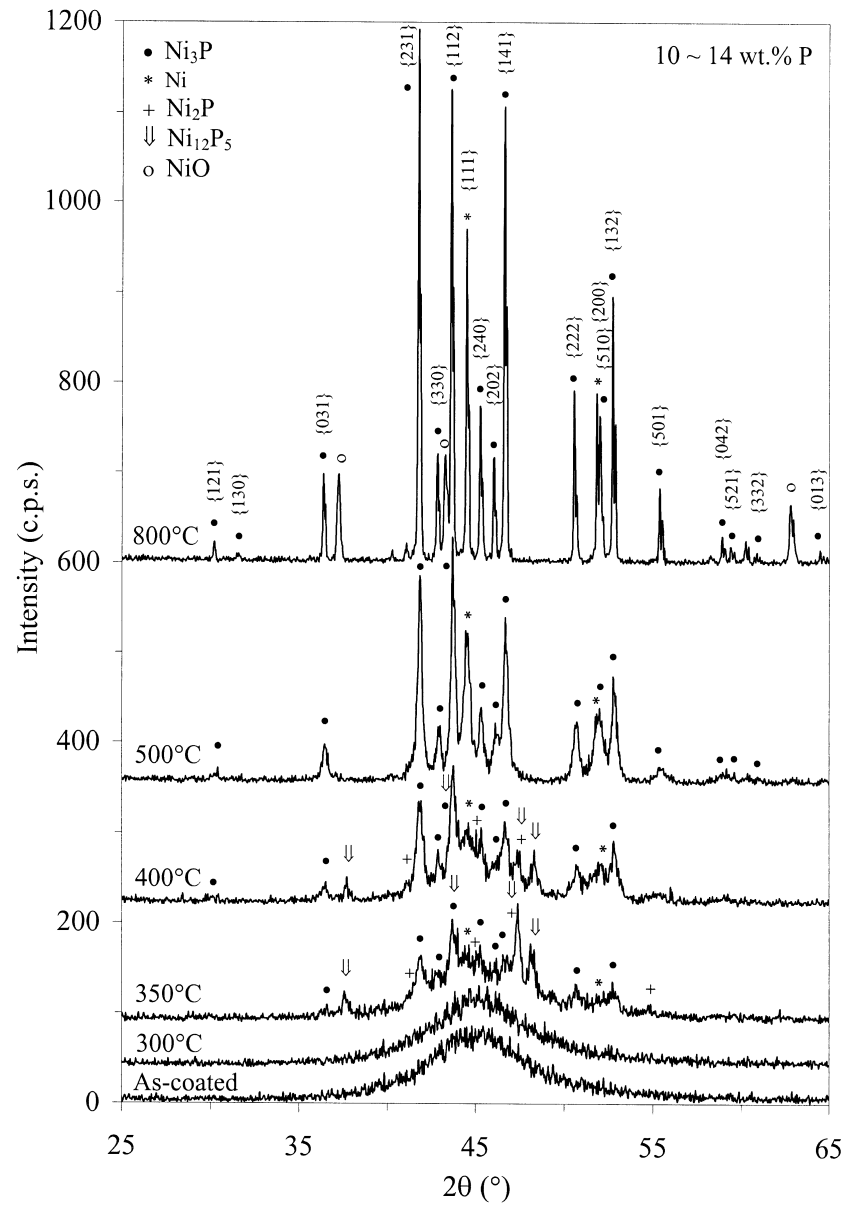

Fig. 2. XRD profiles of the EN deposit with 10-14 wt.\% P (sample B) in as-deposited condition and after heating to the end temperatures of $300-800^{\circ} \mathrm{C}$ at $20^{\circ} \mathrm{C} / \mathrm{min}$. For the sake of clarity the XRD profiles were shifted arbitrarily on the vertical scale.

DSC curves from the substrates alone in the corresponding temperature region (Fig. 3c). The formation of shoulder in the DSC curves might be due to the first stage transformation - the short-range atomic movements and incipient crystallisation of metastable crystalline structures [5,11]. The second stage transformation was the long-range atomic movements and decomposition to the stable phases, associated probably with the major exothermic peak in those DSC curves [11]. In sample A, there might also be processes corresponding to first stage transformation, but they could not be observed due to the peak overlapping in the DSC curves (Fig. 3a). The DSC curves of the mild steel substrates alone showed a broad exothermic region that may be connected to steel recrystallisation. This broad exothermic region was coincident to the second exothermic peak of the DSC curve in sample A. Nevertheless, it can be concluded that the phase transformation temperatures increased with decreasing phosphorus content.

Crystallization activation energies of the EN deposits were derived from the Kissinger plots of $\ln \left(T_{\mathrm{m}}^{2} / \phi\right)$ versus $1000 / R T_{\mathrm{m}}$, using the peak temperatures $\left(T_{\mathrm{m}}\right)$ of crys- 
Table 2

Phase compositions of samples A and B after heating to different end temperatures at a constant heating rate of $20^{\circ} \mathrm{C} / \mathrm{min}$

\begin{tabular}{|c|c|c|}
\hline Temperature $\left({ }^{\circ} \mathrm{C}\right)$ & Sample A (16 wt.\% P) & Sample B (10-14 wt.\% P) \\
\hline As-deposited & $\mathrm{Am}^{\mathrm{a}}$ & Am. ${ }^{a}$ \\
\hline 300 & $\mathrm{Am}^{\mathrm{a}}$ & $\mathrm{Am}^{\mathrm{a}}$ \\
\hline 350 & $\mathrm{Am}^{\mathrm{a}}+\mathrm{Ni}_{2} \mathrm{P}+\mathrm{Ni}_{12} \mathrm{P}_{5}+\mathrm{Ni}_{3} \mathrm{P}$ & $\mathrm{Am}^{\mathrm{a}}+\mathrm{Ni}_{2} \mathrm{P}+\mathrm{Ni}_{12} \mathrm{P}_{5}+\mathrm{Ni}+\mathrm{Ni}_{3} \mathrm{P}$ \\
\hline 400 & $\mathrm{Am}^{\mathrm{a}}+\mathrm{Ni}_{2} \mathrm{P}+\mathrm{Ni}_{12} \mathrm{P}_{5}+\mathrm{Ni}_{3} \mathrm{P}$ & $\mathrm{Am}^{\mathrm{a}}+\mathrm{Ni}_{2} \mathrm{P}+\mathrm{Ni}_{12} \mathrm{P}_{5}+\mathrm{Ni}+\mathrm{Ni}_{3} \mathrm{P}$ \\
\hline 500 & $\mathrm{Am}^{\mathrm{a}}+\mathrm{Ni}_{3} \mathrm{P}$ & $\mathrm{Am}^{\mathrm{a}}+\mathrm{Ni}+\mathrm{Ni}_{3} \mathrm{P}$ \\
\hline 800 & $\mathrm{Ni}_{3} \mathrm{P}$ & $\mathrm{NiO}+\mathrm{Ni}+\mathrm{Ni}_{3} \mathrm{P}$ \\
\hline
\end{tabular}

${ }^{\mathrm{a}}$ Am., amorphous phase.

tallization process represented by the major exothermic peak of the DSC curves, at different heating rates $(\phi)$ [19]. The peak temperatures of samples A and B ranged from
325 to $354^{\circ} \mathrm{C}$ and 346 to $375^{\circ} \mathrm{C}$, respectively (Fig. 3). The calculated activation energies could be compared with the self-diffusion activation energy of nickel, $289 \mathrm{~kJ} / \mathrm{mol}$ [20].

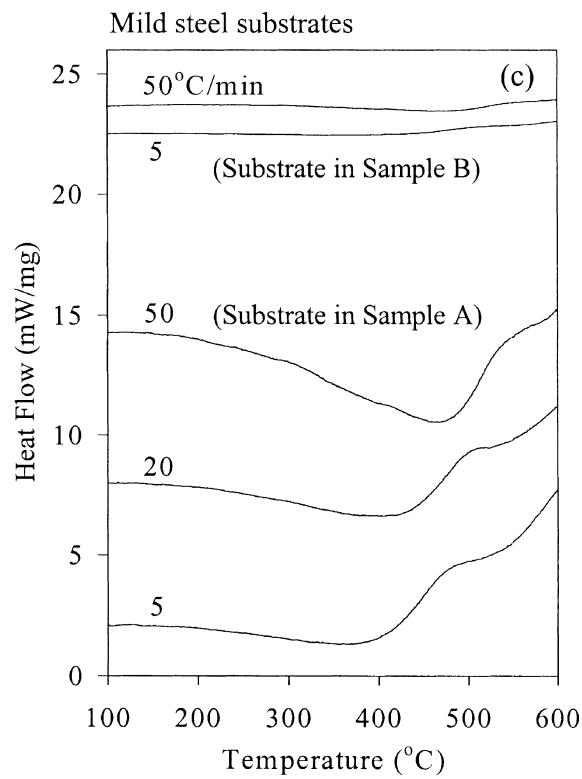

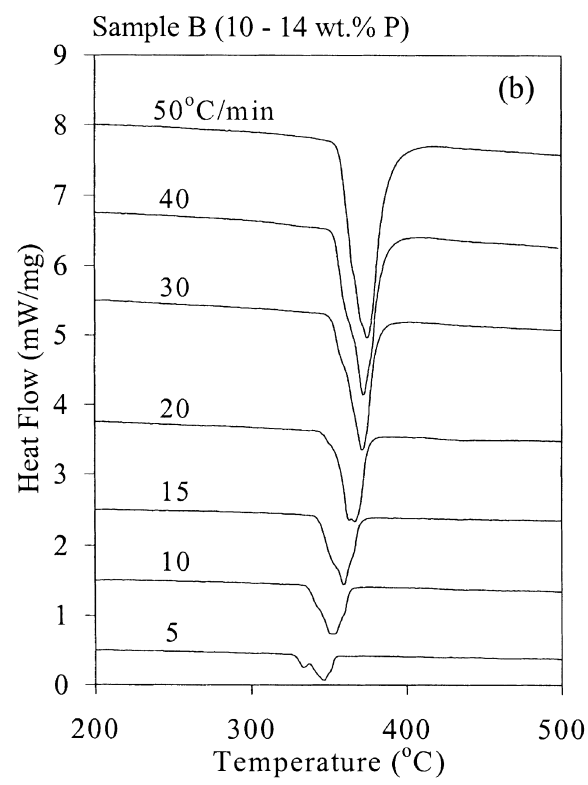

Fig. 3. DSC curves of (a) sample A, (b) sample B and (c) mild steel substrates at the heating rate of $5-50^{\circ} \mathrm{C} / \mathrm{min}$. For the sake of clarity the calorimetric curves were shifted arbitrarily on the vertical scale. 
The activation energy of sample B $(225 \pm 20 \mathrm{~kJ} / \mathrm{mol})$ was slightly higher than that of sample A $(210 \pm 17 \mathrm{~kJ} / \mathrm{mol})$. Hence, it was suggested that the activation energy of the EN deposits increased with lower phosphorus content.

\subsection{Effects of heating process}

The results showed that both the phase composition and phase transformation behaviour of the EN deposits depended on the heating temperatures. It was found that the effect of heating rate on the phase composition and transformation behaviour of sample B deposit was also considerable. In addition, the cooling rate was found to have no significant effect on the resultant phase composition of sample A deposit, from a heating temperature that was far higher than the crystallisation temperature of the deposit.

The XRD profiles of sample B heated to $300-800^{\circ} \mathrm{C}$ at $20^{\circ} \mathrm{C} / \mathrm{min}$ showed different phase compositions (Fig. 2). After heating to $300^{\circ} \mathrm{C}$, changes in sample B were not observed. Only a single broad amorphous profile was found. This was also confirmed by the DSC curve of the sample (Fig. 3b), which shows no major crystallisation reaction up to that temperature. At 350 and $400^{\circ} \mathrm{C}$, the diffraction peaks corresponding to the metastable $\mathrm{Ni}_{2} \mathrm{P}$ and $\mathrm{Ni}_{12} \mathrm{P}_{5}$, f.c.c. nickel and stable $\mathrm{Ni}_{3} \mathrm{P}$ phases in the XRD profiles of sample $\mathrm{B}$ suggest the ongoing phase transformation processes. This was in agreement with the major exothermic peak of crystallisation process in the DSC curves of sample $\mathrm{B}$ in the same temperature range. The XRD profiles of the sample also show the remains of the amorphous phase in the deposits. Hence, the microstructure of sample $\mathrm{B}$ was suggested to be a mixture of amorphous and crystalline phases. At 400 and $500^{\circ} \mathrm{C}$, the diffraction peaks corresponding to the f.c.c. nickel and $\mathrm{Ni}_{3} \mathrm{P}$ phases were intensified with decreasing amount of amorphous phase. The $\mathrm{Ni}_{2} \mathrm{P}$ and $\mathrm{Ni}_{12} \mathrm{P}_{5}$ metastable phases were decomposed completely after the heating process to $500^{\circ} \mathrm{C}$. Consequently, the crystallisation process in sample B was believed to be near completion. At 500 and $800^{\circ} \mathrm{C}$, numerous minor diffraction peaks developed in the deposit with increased intensities and further refinement of the existing diffraction peaks. The f.c.c. nickel and $\mathrm{Ni}_{3} \mathrm{P}$ phases were the only two dominant resultant phases at this stage. Consequently, sample B was believed to have completed the crystallisation process and developed a fully crystalline microstructure. In sample $\mathrm{A}$, the heating temperatures affected the microstructural properties and phase transformation behaviour of the deposit in a similar way (Figs. 1 and 3a), except that there was no nickel phase in the deposit.

The effect of the heating rate on the EN deposits during heating process was studied through XRD and DSC analyses on sample B. The XRD profiles of sample B specimens after heating to $400^{\circ} \mathrm{C}$, at different heating rates of 5 and $20^{\circ} \mathrm{C} / \mathrm{min}$, are compared in Fig. 4a. There were
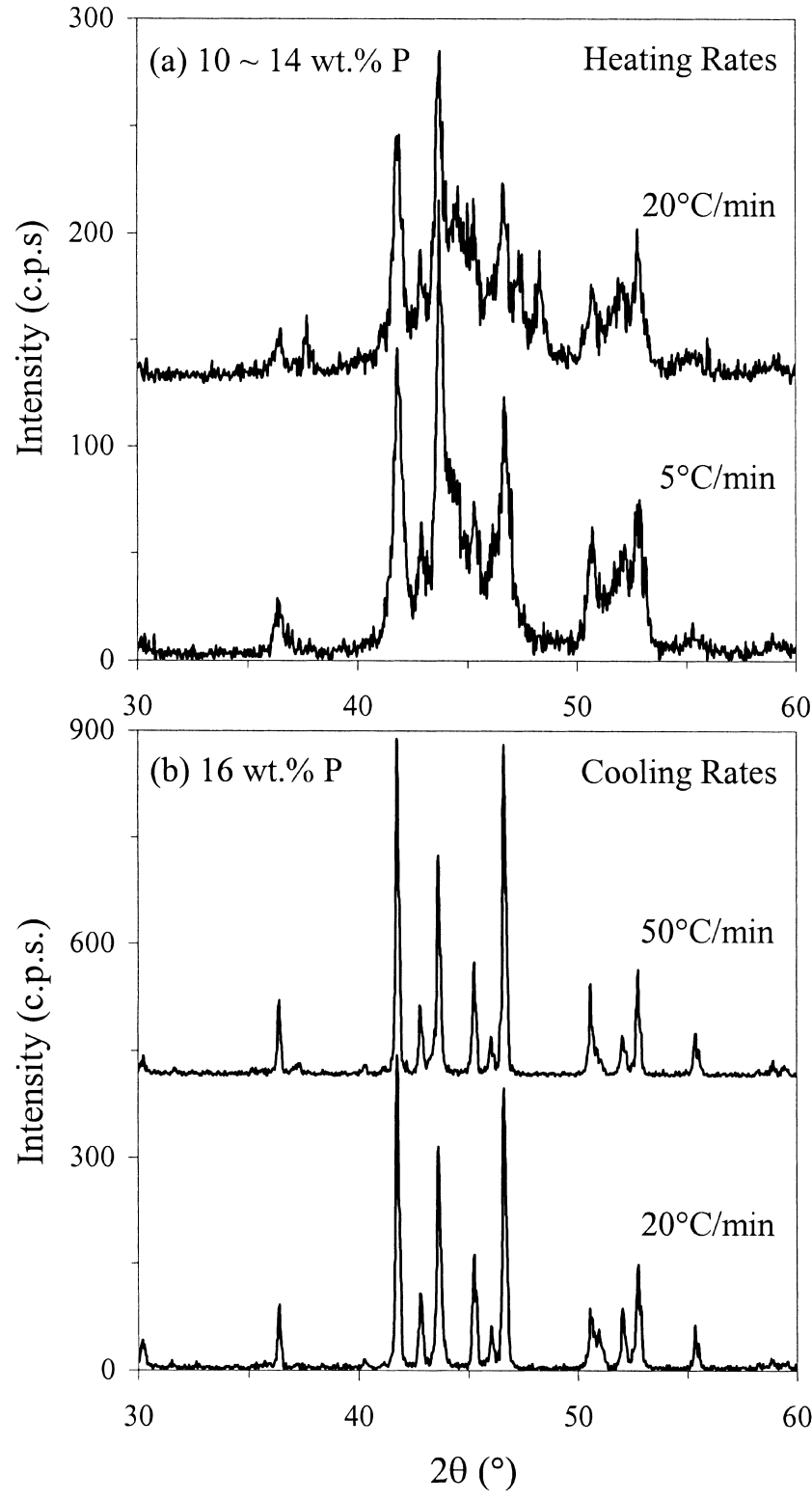

Fig. 4. XRD profiles showing the effects of (a) heating and (b) cooling rates on the crystallization of samples $\mathrm{B}$ and A deposits, respectively. The heating end temperatures were $400^{\circ} \mathrm{C}$ for sample $\mathrm{B}$, and $800^{\circ} \mathrm{C}$ for sample A at $20^{\circ} \mathrm{C} / \mathrm{min}$. For the sake of clarity the XRD profiles were shifted arbitrarily on the vertical scale.

$\mathrm{Ni}_{2} \mathrm{P}$ and $\mathrm{Ni}_{12} \mathrm{P}_{5}$ metastable phases in the specimen that was heated at the higher heating rate. It should be mentioned that, however, the sample B specimens used in the present study for XRD analyses were heated to a temperature $\left(400^{\circ} \mathrm{C}\right)$ not much higher than the peak crystallisation temperature $\left(346\right.$ and $366^{\circ} \mathrm{C}$, respectively, at 5 and $\left.20^{\circ} \mathrm{C} / \mathrm{min}\right)$. So the effects of the heating rate on the microstructural property of the deposits as regards temperatures far before and after the major crystallisation reaction deserve further study. In addition to this, the DSC curves of sample B in Fig. 3b show that the major crystallisation reaction, indicated by the major exothermic 
peak, was delayed by the increase in heating rates. Similar result was observed in the DSC curves of sample A (Fig. 3a). The increase in heating rates also correspondingly increased the area of exothermic peaks in the DSC curves. This phenomenon is caused by the higher rate of exothermic heat flow and shorter crystallisation time at high heating rate.

The effects of the cooling rate on the resultant microstructure of the sample A specimens were not significant. The specimens were heated to $800^{\circ} \mathrm{C}$ at a constant rate of $20^{\circ} \mathrm{C} / \mathrm{min}$. Then they were cooled down at different cooling rates of 20 and $50^{\circ} \mathrm{C} / \mathrm{min}$. The XRD profiles of the specimens cooled at different cooling rates were similar (Fig. 4b). However, the results indicated only the effect of cooling rate on the microstructural property of the deposit that had been heated to a temperature $\left(800^{\circ} \mathrm{C}\right)$ much higher than the crystallisation temperatures of the deposit. Hence, the effects of cooling rate on the microstructural property of the EN deposits during major crystallisation reaction deserve further study.

\subsection{Degree of phase transformation}

The integrated intensities of amorphous, metastable, nickel and $\mathrm{Ni}_{3} \mathrm{P}$ phases were calculated from the corresponding reflections in the XRD profiles of samples $\mathrm{A}$ and $\mathrm{B}$ using the computer program Pro-Fit. The ratio of the integrated intensity of amorphous phase $\left(I_{\text {Amorp }}\right)$ to the total integrated intensity $\left(I_{\text {Total }}\right)$ shows the relative proportion of the amorphous phase remaining in the deposit. Conse- quently, the degree of transformation in the EN systems can be represented by the variation of this integrated intensity ratio with the heating temperature. In Fig. 5, the integrated intensity ratios of the amorphous phase $\left(I_{\text {Amorp }} /\right.$ $I_{\text {Total }}$ ) remain constant to $300^{\circ} \mathrm{C}$, indicating that no significant crystallization reaction had occurred in either sample. From 300 to $500^{\circ} \mathrm{C}$, the $I_{\text {Amorp }} / I_{\text {Total }}$ decreased sharply to a very low level in both samples. The major crystallization reactions in the deposits took place at this temperature range. From 500 to $800^{\circ} \mathrm{C}$, the $I_{\text {Amorp }} / I_{\text {Total }}$ of both samples further decreased to zero, indicating that complete crystallization was achieved before $800^{\circ} \mathrm{C}$.

\subsection{SEM and electron microprobe analysis}

Fig. 6a shows cross-section of sample A in as-deposit condition. The thicknesses of the coated deposit on both sides of the substrate were remarkably uniform $(2.9 \mu \mathrm{m}$ on each side). The appearance of the deposits was homogeneous although they had been plated through repeated plating process. There were numerous voids (see arrow) found of different shapes and sizes in the mild steel substrate. However, Fig. $6 \mathrm{~b}$ and $6 \mathrm{c}$ clearly shows that thermally activated diffusion process took place between the coated deposits and the mild steel substrate underneath. The deposit heated to $400^{\circ} \mathrm{C}$ showed an increase in iron content, with a relative decrease in nickel content (Table 3). It was believed that the $\mathrm{Ni}$ had diffused into the substrate during diffusion process, indicated by the increase of $\mathrm{Ni}$ level in the diffusion layer (see arrow).
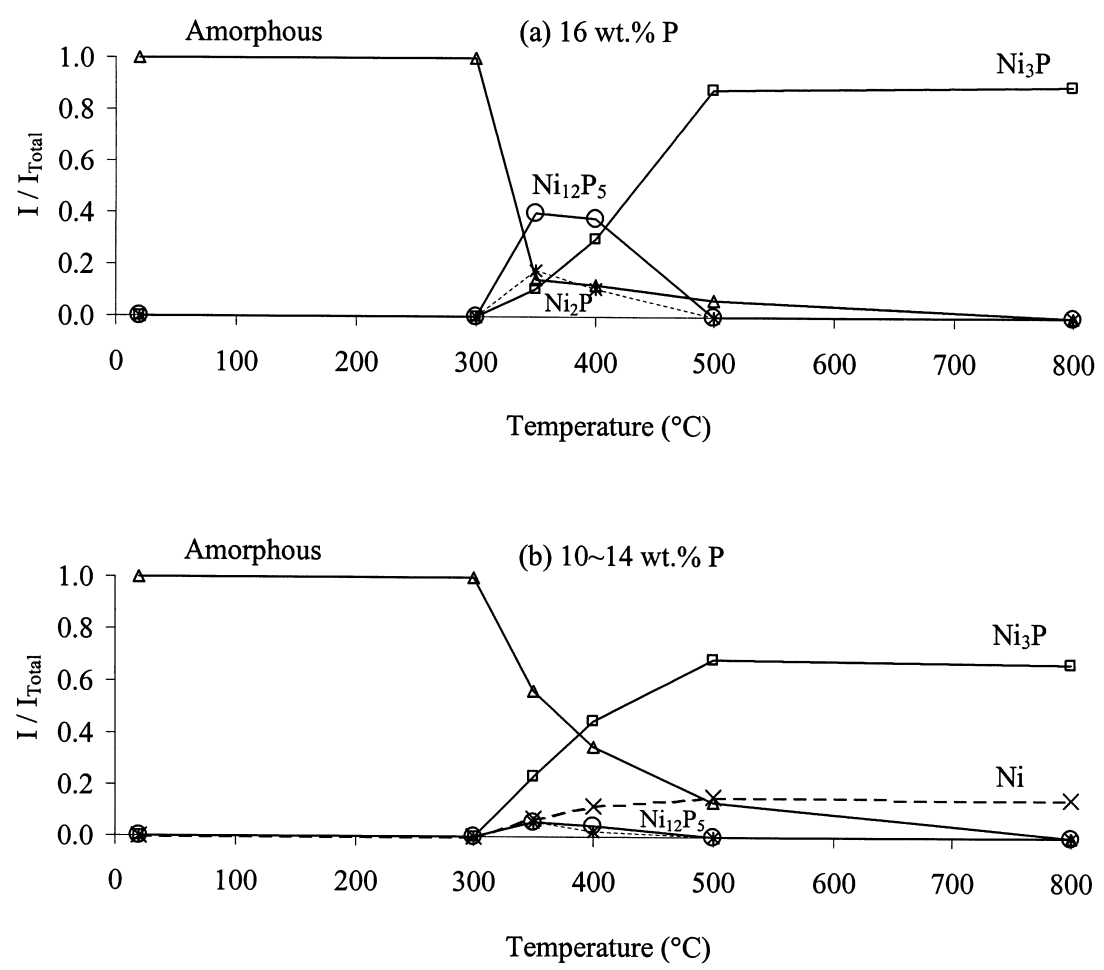

Fig. 5. Variation of the integrated intensity ratio $\left(I / I_{\text {Total }}\right)$ over heating temperature in (a) sample A and (b) sample B. 

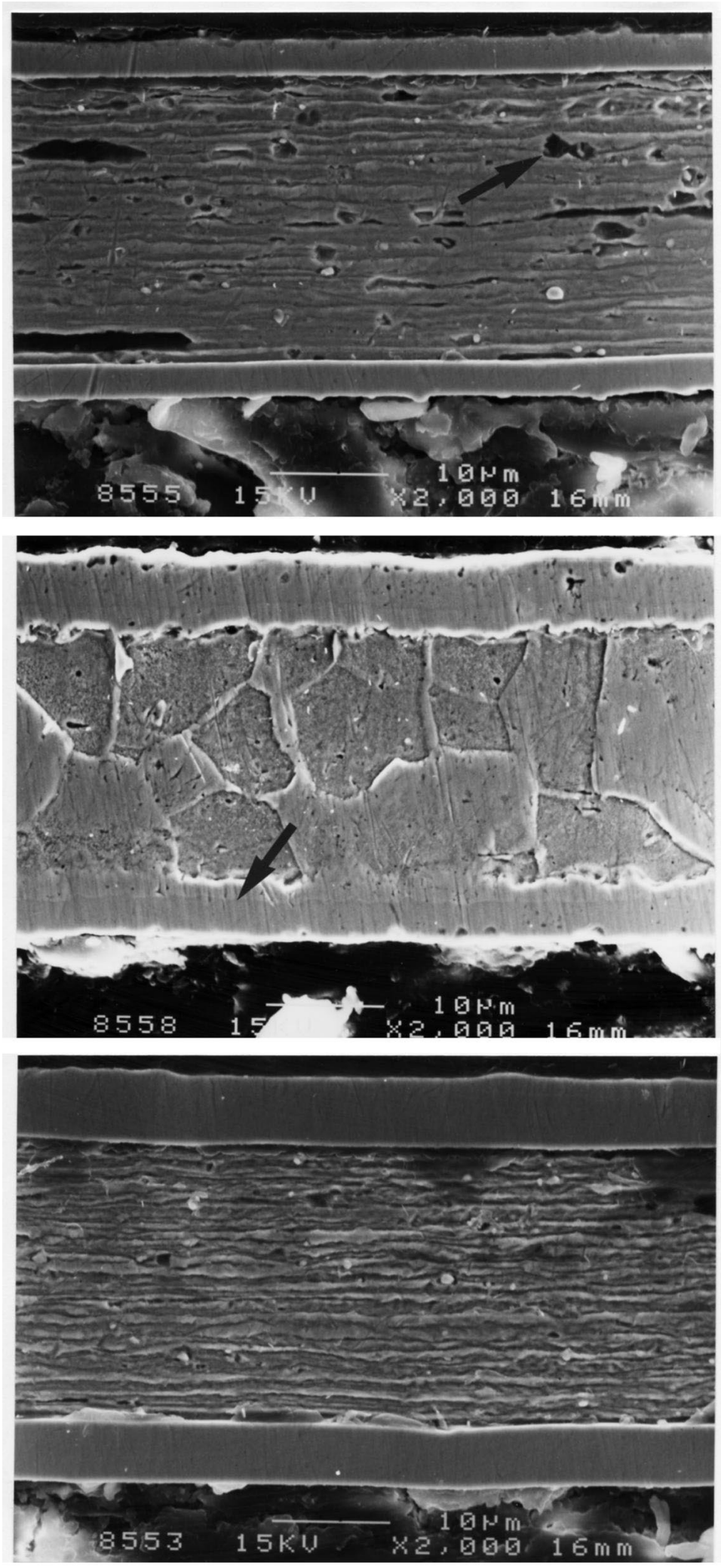

Fig. 6. Scanning electron micrographs of sample A (16 wt.\% P) deposit in (a) as-deposited condition, and after heating to (b) $400^{\circ} \mathrm{C}$ and (c) $800^{\circ} \mathrm{C}$.

However, there was neither nickel nor phosphorus in the substrate at the point far from the deposit-substrate interface, suggesting that the diffusion process did not involve the entire mild steel substrate. After heating to $800^{\circ} \mathrm{C}$, the Fe content in the deposit was reduced to a level about half that of the as-coated deposit. It is possible that 
Table 3

Electron microprobe analysis of the average compositions in sample A (16 wt. \% P) in as-deposited condition and after heating to 400 and $800^{\circ} \mathrm{C}$

\begin{tabular}{|c|c|c|c|c|c|c|c|c|c|}
\hline \multirow[t]{2}{*}{ Location } & \multicolumn{3}{|c|}{ As-deposited } & \multicolumn{3}{|l|}{$400^{\circ} \mathrm{C}$} & \multicolumn{3}{|l|}{$800^{\circ} \mathrm{C}$} \\
\hline & $\mathrm{Ni}$ & $\mathrm{P}$ & $\mathrm{Fe}$ & $\mathrm{Ni}$ & $\mathrm{P}$ & $\mathrm{Fe}$ & $\mathrm{Ni}$ & $\mathrm{P}$ & $\mathrm{Fe}$ \\
\hline $\begin{array}{l}\text { Deposit } \\
\text { Diffusion layer }\end{array}$ & $81.2 \pm 1.1$ & $15.5 \pm 0.2$ & $3.4 \pm 0.2$ & $\begin{array}{l}78.4 \pm 1.0 \\
26.6 \pm 0.7\end{array}$ & $\begin{array}{r}16.5 \pm 0.2 \\
0.4 \pm 0.1\end{array}$ & $\begin{array}{r}5.1 \pm 0.3 \\
73 \pm 0.8\end{array}$ & $82.7 \pm 1.1$ & $15.5 \pm 0.2$ & $1.9 \pm 0.2$ \\
\hline
\end{tabular}

the $\mathrm{Fe}$ had migrated from the deposit to the depositsubstrate interface during diffusion process. Again, the diffusion process was believed to not involve the entire mild steel substrate, as nickel and phosphorus were still absent in the substrate at the point far from the depositsubstrate interface. Film growth after the heating processes (Fig. 6b and 6c) has increased the films' thicknesses to 4.8 and $5 \mu \mathrm{m}$, respectively. The increase might be related to phase transformation in the deposits, as indicated by the XRD profiles of sample A (Fig. 1). The same kind of diffusion process would be found in the deposit-substrate interfaces of sample B.

\section{Summary and conclusions}

Differential scanning calorimetry, X-ray diffraction, scanning electron microscopy, and electron microprobe analyses on the EN deposits have led to the following conclusions:

Both the deposits with 16 and 10-14 wt.\% P were amorphous in as-deposited condition.

Sequence of phase transformation for the $16 \mathrm{wt} \% \mathrm{P}$ deposit was: amorphous phase $\rightarrow$ co-existence of stable $\mathrm{Ni}_{3} \mathrm{P}$, and metastable $\mathrm{Ni}_{2} \mathrm{P}, \quad \mathrm{Ni}_{12} \mathrm{P}_{5}$ and unidentified phases $\rightarrow$ stable $\mathrm{Ni}_{3} \mathrm{P}$ phase.

Sequence of phase transformation for the 10-14 wt.\% P deposit was: amorphous phase $\rightarrow$ co-existence of stable $\mathrm{Ni}_{3} \mathrm{P}$, f.c.c. nickel, and metastable $\mathrm{Ni}_{2} \mathrm{P}, \mathrm{Ni}_{12} \mathrm{P}_{5}$ and unidentified phases $\rightarrow$ stable $\mathrm{Ni}_{3} \mathrm{P}$ and f.c.c. nickel phases.

Phase transformation temperatures of the samples increased with increasing heating rate, and decreasing phosphorus content.

The deposit with lower phosphorus content had higher crystallisation activation energy.

Effect of heating rate on the microstructural property of 10-14 wt.\% P deposit was significant for the heating temperature that is close to the crystallisation process. Effect of cooling rate on the phase constitution of the 16 wt.\% P deposit was not significant for heating to the temperature far above the crystallisation process.

SEM analysis indicated the film growth of the $16 \mathrm{wt} . \%$ $\mathrm{P}$ coated deposit after heating processes. The diffusion process between the coated deposit and its mild steel substrate did not occur through the entire depth of mild steel substrate.

\section{Acknowledgements}

The authors wish to thank R. Laughton of Lea Manufacturing in UK, for providing the nickel-phosphorus samples and helpful technical advice on the present work. Technical support from Dr Z. Guo (QUB) with the DSC analysis is also gratefully appreciated.

\section{References}

[1] N.M. Martyak, Chem. Mater. 6 (1994) 1667-1674.

[2] Q.X. Mai, R.D. Daniels, H.B. Harpalani, Thin Solid Films 166 (1988) 235-247.

[3] M.R. Lambert, D.J. Duquette, Thin Solid Films 177 (1989) 207223.

[4] P.S. Kumar, P.K. Nair, J. Mater. Proc. Tech. 56 (1996) 511-520.

[5] E.M. Ma, S.F. Luo, P.X. Li, Thin Solid Films 166 (1988) 273-280.

[6] E. Vafaei-Makhsoos, E.L. Thosmas, L.E. Toth, Metall. Trans. 9A (1978) 1449.

[7] R.C. Agarwala, S. Ray, Z. Metallkd. 79 (2) (1988) 472-475.

[8] S.H. Hur, J.H. Jeong, D.N. Lee, J. Mater. Sci. 25 (5) (1990) 2573-2584.

[9] J.P. Randin, P.A. Maire, E. Saurer, H.E. Hintermann, J. Electrochem. Soc. 114 (12) (1967) 442-445.

[10] A. Cziraki, B. Fogarassy, I. Bokonyi, K. Tompa, T. Bagi, Z. Hegedus, Investigation of Chemically Deposited and Electroplated Amorphous Ni-P Alloys, Central Research Institute for Physics, Budapest, 1980.

[11] S.H. Park, D.N. Lee, J. Mater. Sci. 23 (1988) 1643-1654.

[12] S.L. Chow, N.E. Hedgecock, M. Schiesinger, J. Rezek, J. Electrochem. Soc. 119 (1972) 1614.

[13] A.W. Goldenstein, W. Rostoker, F. Schossberger, G. Gutzeit, J. Electrochem. Soc. 104 (1957) 104.

[14] R.C. Agarwala, S. Ray, Z. Metallkd. 83 (3) (1992) 199-202.

[15] Y.Z. Zhang, K. Zhang, J.H. Fan, S.M. Zhang, Trans. Nonferrous Met. Soc. Chin. 8 (4) (1998) 642-647.

[16] W. Sha, C.J. Murphy, J. Quinn, J. Alloys Comp. 287 (1999) L7-L9.

[17] Lea Manufacturing Company, Niklad electroless nickel plating systems, in Electroless Nickel Technology Training Course Notes, Buxton, UK, 1999, pp. 4-6.

[18] B. Grzeta, H. Toraya, Croatica Chem. Acta 67 (2) (1994) 273-288.

[19] H.E. Kissinger, Anal. Chem. 29 (1957) 1702.

[20] D.S. Wilkinson, Mass Transport in Solids and Fluids, Cambridge University Press, Cambridge, 2000, p. 242. 